\title{
High lactate levels are predictors of major complications after cardiac surgery
}

\author{
Ludhmila A. Hajjar, MD, PhD, ${ }^{a}$ Juliano P. Almeida, MD, ${ }^{a}$ Julia T. Fukushima, MSc, ${ }^{a}$ \\ Andrew Rhodes, MD, PhD, ${ }^{\mathrm{b}}$ Jean-Louis Vincent, $\mathrm{MD}, \mathrm{PhD},{ }^{\mathrm{c}}$ Eduardo A. Osawa, MD, ${ }^{\mathrm{a}}$ \\ and Filomena R. B. G. Galas, MD, $\mathrm{PhD}^{\mathrm{a}}$
}

\begin{abstract}
Objective: Although hyperlactatemia after cardiac surgery is common, the implications of raised levels remain controversial. The aim of this study was to evaluate whether high lactate levels after cardiac surgery are predictors of major complications including mortality.
\end{abstract} Patients and Methods: This was a substudy of TRACS (Transfusion Requirements After Cardiac Surgery),
which was designed as a prospective, randomized, controlled trial evaluating the effects of a transfusion strategy
on morbidity and mortality.

\begin{abstract}
Results: Of the 502 patients enrolled, $52(10 \%)$ had at least 1 major complication. Patients with complications were older, had a higher EuroSCORE, lower left ventricular ejection fraction, lower preoperative hemoglobin, a higher prevalence of renal disease, and received more blood transfusions than the group without complications. Lactate levels were higher in the group with complications at the end of surgery (3.6 mmol/L [2.8-5.1] vs 3.3 $\mathrm{mmol} / \mathrm{L}$ [2.2-4.8]; $P=.018)$, immediately after intensive care unit (ICU) admission (0 hour) $(4.4 \mathrm{mmol} / \mathrm{L}$ [3.1-8.4] vs $4 \mathrm{mmol} / \mathrm{L}$ [2.6-6.4]; $P=.048) ; 6$ hours $(4 \mathrm{mmol} / \mathrm{L}[2.7-5.8]$ vs $2.6 \mathrm{mmol} / \mathrm{L}[2-3.6], P<.001)$, and 12 hours after admission $(2.3 \mathrm{mmol} / \mathrm{L}$ [1.8-3.2] vs $1.7 \mathrm{mmol} / \mathrm{L}[1.3-2] ; P<.001)$. In a multivariate model, higher age (odds ratio [OR], 1.048, 95\% confidence interval $[\mathrm{CI}], 1.011-1.086 ; P=.010$ ), left ventricular ejection fraction (LVEF) lower than 40\% (OR, 3.03; 95\% CI, 1.200-7.510; $P=.019$ compared with LVEF of $40 \%-59 \%$; OR, 3.571; $95 \%$ CI, 1.503-8.196; $P=.004$ compared with LVEF higher than $60 \%$ ), higher EuroSCORE (OR, 1.138; 95\% CI; 1.007-1.285; $P=.038)$, red blood cell transfusion (OR, $1.230 ; 95 \% \mathrm{CI}$, 1.086-1.393; $P=.001)$, and lactate levels 6 hours after ICU admission (OR, 3.28, 95\% CI; 1.61-6.69; $P=.001)$ are predictors of major complications.
\end{abstract}

Conclusions: Hyperlactatemia 6 hours after ICU admission is an independent risk factor for worse outcomes in adult patients after cardiac surgery. (J Thorac Cardiovasc Surg 2013;146:455-60)

Hyperlactatemia is frequently encountered during and after cardiac surgery and has many causes that include tissue hypoxia as well as nonhypoxic causes such as drug therapy, cardioplegia, hypothermia, and cardiopulmonary bypass (CPB) ${ }^{1-4}$ In sepsis and shock states, high levels of blood lactate have been associated with worse outcomes, including mortality. ${ }^{5,6}$

After cardiac surgery, morbidity and mortality are related directly to the preoperative status of the patient, as well as to specific anesthetic, surgical, and postoperative factors. The

\footnotetext{
From the Surgical Intensive Care Unit and Department of Anesthesiology, ${ }^{a}$ Heart Institute (InCor), Hospital das Clinicas da Faculdade de Medicina da Universidade de São Paulo, São Paulo, Brazil; the Department of Critical Care, ${ }^{\mathrm{b}}$ St George's Healthcare NHS Trust and St George's University of London, London, United Kingdom; and the Department of Intensive Care, ${ }^{\mathrm{c}}$ Erasme Hospital (Libre Universite of Bruxelles), Brussels, Belgium.

Disclosures: Authors have nothing to disclose with regard to commercial support. Clinical Trial Registry Number: NCT 01021631.

Received for publication Aug 30, 2012; revisions received Dec 13, 2012; accepted for publication Feb 8, 2013; available ahead of print March 18, 2013.

Address for reprints: Ludhmila A. Hajjar, MD, PhD, Av Dr Eneas Carvalho Aguiar,

44, São Paulo, Brazil 05403000 (E-mail: ludhmila@usp.br).

$0022-5223 / \$ 36.00$

Copyright (c) 2013 by The American Association for Thoracic Surgery

http://dx.doi.org/10.1016/j.jtcvs.2013.02.003
}

maintenance of appropriate hemodynamic goals is essential to improve outcomes after cardiac surgery. ${ }^{1}$ Perfusion markers such as central venous oxygen saturation and blood lactate may, therefore, represent important tools for the management of these patients. ${ }^{7}$ The predictive role of hyperlactatemia as a prognostic factor in these patients is not well understood.

The aim of this study was to evaluate whether high lactate levels after cardiac surgery are predictors of major complications, including acute respiratory distress syndrome (ARDS), cardiogenic shock, acute kidney injury needing renal replacement therapy, and mortality.

\section{METHODS}

The Transfusion Requirements After Cardiac Surgery (TRACS) study, which has been previously reported, was designed as a prospective, randomized, noninferiority, controlled trial to look into blood transfusion thresholds after elective cardiac surgery. ${ }^{8}$ Consecutive adult patients who were scheduled for elective cardiac surgery with CPB between February 9, 2009, and February 1, 2010, were enrolled. We excluded patients requiring surgery in an emergency situation, ascending or descending thoracic aortic procedures, left ventricular aneurysm resection, inability to receive blood products, pregnancy, cancer, congenital heart defect, hepatic dysfunction, end-stage renal disease, and the refusal to consent. The study was approved by the Heart Institute Ethics Committee of the Clinics 


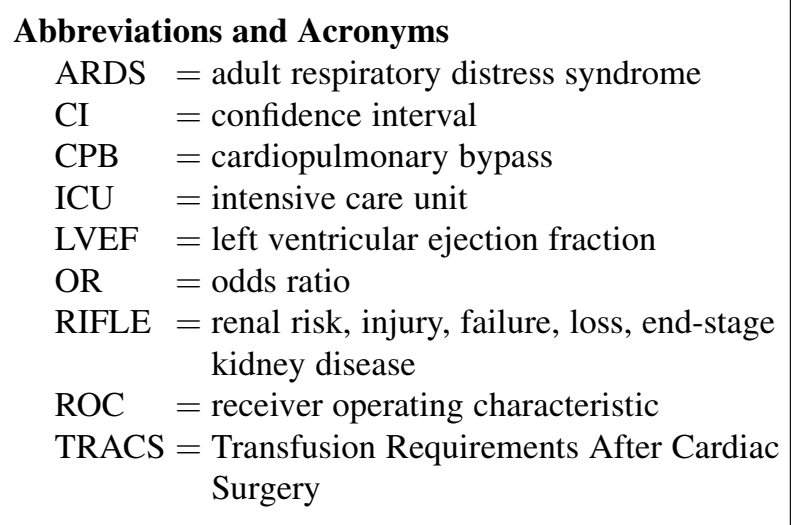

Hospital, University of São Paulo, and written informed consent was obtained from all patients before enrollment. Patients were randomly assigned to a liberal (hematocrit values maintained $>30 \%$ ) or restrictive strategy group (hematocrit values maintained $>24 \%$ ) from the beginning of the operation until discharge from the intensive care unit (ICU).

In this substudy, we assessed the values of blood lactate measurements as predictors of postoperative complications in the overall population of 502 patients. Blood lactate levels and blood gases were determined routinely iRadiometer ABL 835 blood gas analyzer (Radiometer Medical A/S, Bronshoj, Denmark) during surgery in the operating room, immediately on the arrival to the ICU (0 hours), and at 6 and 12 hours after ICU admission.

\section{Outcome Measures}

A composite end point for postoperative complications was used and defined as a combination of 30-day all cause mortality and severe morbidity (cardiogenic shock, ARDS, or acute kidney injury needing renal replacement therapy during the hospital stay). Cardiogenic shock was defined as the presence of tachycardia, hypotension, and poor perfusion associated with a central venous oxygen saturation less than $65 \%$, cardiac index equal to or lower than $2.2 \mathrm{~L} \cdot \mathrm{min}^{-1} \cdot \mathrm{m}^{-2}$, or metabolic acidosis (decrease in base deficit $>4$ ) in the absence of a cause other than heart failure, which occurred after ICU admission. ${ }^{9,10}$ ARDS was defined by standard criteria. ${ }^{11}$ Renal function was evaluated daily using the RIFLE (renal risk, injury, failure, loss, end-stage kidney disease) classification. $^{10}$

\section{Statistical Analysis}

Results are expressed as means with standard deviation or medians with interquartile ranges, as appropriate. Normality was assessed with the Kolmogorov-Smirnov test. The relationships between the complications and potential risk factors identified by univariate analysis were assessed using a $\chi^{2}$ test, Fisher's exact test, likelihood ratio test, $t$ test, or MannWhitney $U$ test. Receiver operating characteristic (ROC) curves were constructed, and the area under the ROC curve was determined to assess the discriminant ability of the lactate concentration measured at intraoperative, at ICU admission (0 hours), 6 hours, and 12 hours after ICU admission to predict complications. Negative predictive value and positive predictive value to predict complications were calculated. The ROC curves also were used to determine the cutoff values of lactate to predict complications. The cutoff was the value that maximized the sensitivity and specificity.

A forward multiple logistic regression analysis was then performed to estimate independent predictive factors for complications. This model included risk factors that were first identified by univariate analysis
$(P<.1)$. And all tests were 2-tailed. Statistical analyses were performed using SPSS version 18 (SPSS, Inc, Chicago, Ill).

\section{RESULTS}

A total of 502 patients were enrolled in the original study, from which $52(10.4 \%)$ patients had at least 1 major complication. Thirty-six (7.2\%) patients had 2 or more complications. Death occurred in $26(5.2 \%)$ patients, cardiogenic shock in $34(6.8 \%)$, acute kidney injury needing renal replacement therapy in $23(4.6 \%)$, and ARDS in $7(1.4 \%)$ patients.

This group of patients was older $(67 \pm 11$ vs $59 \pm 12$ years; $P<.001)$ and had a lower prevalence of male gender (22 [42\%] vs 288 [64\%]; $P=.002$ ) than the group without complications. There was no significant difference in comorbidities, except for a higher prevalence of chronic renal disease (11 [22\%] vs $41[9 \%] ; P=.004)$ in patients who had complications (Table 1). The prevalence of patients with a lower preoperative left ventricular ejection fraction (LVEF) was higher in the group with complications as compared with the group without complications (LVEF $<40 \%$, $16[31 \%]$ vs $53[12 \%] ; P=.001)$. Patients with complications also had a higher operative risk, characterized by a higher EuroSCORE (7 [5-9] vs 4 [3-6]; $P<.001)$ and a lower preoperative hemoglobin level $(12.6 \pm 2.1$ vs $13.3 \pm 1.7 \mathrm{gm} / \mathrm{dL} ; P=.009$ ) when compared with patients without complications (Table 1). The group with complications had a longer duration of hospital stay ( $14 \pm 5$ days vs $9 \pm 4$ days; $P<.001$ ) than those who did not.

The patients in whom major complications developed were more likely to undergo valve surgery (19 [37\%] vs $140[31 \%] ; P<.001)$ or a combined valve and graft procedure $(11[21 \%]$ vs $25[6 \%] ; P<.001)$ compared with the group without complications. They also had a longer duration of CPB $(109 \pm 36$ minutes vs $93 \pm 29$ minutes; $P<.001)$ and a lower hematocrit $(27 \% \pm 5 \%$ vs $25 \% \pm 6 \% ; P=.019)$, higher final lactate levels at odds ratio (OR) $(3.6$ [2.8-5.1] $\mathrm{mmol} / \mathrm{L}$ vs $3.3[2.2-4.8] \mathrm{mmol} / \mathrm{L}$; $P=.018)$, and lower venous oxygen saturation $(74 \% \pm 11 \%$ vs $82 \% \pm 7 \% ; P<.001)$ during surgery than the other patients. They required more blood products during surgery than did the group without complications (2 [1-3] vs 1 [0-2]; $P<.001$ ), and after ICU admission (2 [2-4] vs $1[0-2] ; P<.001)$. There was no significant difference between groups regarding the strategy of red blood cell transfusion (Tables 2 and 3).

Patients in whom complications developed had higher lactate levels immediately after ICU admission (4.4 [3.1-8.4] vs $4.0 \mathrm{mmol} / \mathrm{L}[2.6-6.4] ; P=.048) ; 6$ hours (4 [2.7-5.8] vs $2.6 \mathrm{mmol} / \mathrm{L}[2-3.6] ; P<.001)$; and 12 hours after admission (2.3 [1.8-3.2] vs $1.7 \mathrm{mmol} / \mathrm{L}$ [1.3-2]; $P<.001$ ) (Table 2).

Lactate levels of $3 \mathrm{mmol} / \mathrm{L}$ after 6 hours of ICU stay and of $2 \mathrm{mmol} / \mathrm{L}$ after 12 hours of ICU stay were associated with 
TABLE 1. Univariate variable screening findings

\begin{tabular}{|c|c|c|c|c|}
\hline \multirow[b]{2}{*}{ Variable } & \multirow[b]{2}{*}{ Total } & \multicolumn{2}{|c|}{ Complications } & \multirow[b]{2}{*}{$P$ value } \\
\hline & & No $(n=450)$ & Yes $(\mathbf{n}=\mathbf{5 2})$ & \\
\hline Age (y), mean (SD) & $60 \pm 12$ & $59 \pm 12$ & $67 \pm 11$ & $<.001$ \\
\hline Men & $310(62 \%)$ & $288(64 \%)$ & $22(42 \%)$ & .002 \\
\hline Body mass index $\left(\mathrm{kg} / \mathrm{m}^{2}\right)$, mean (SD) & $26 \pm 4$ & $26 \pm 4$ & $26 \pm 5$ & .967 \\
\hline \multicolumn{5}{|l|}{ Comorbid conditions } \\
\hline Hypertension & $393(78 \%)$ & $350(78 \%)$ & $43(83 \%)$ & .416 \\
\hline Diabetes & $165(33 \%)$ & $144(32 \%)$ & $21(40 \%)$ & .236 \\
\hline Dyslipidemia & $286(57 \%)$ & $253(56 \%)$ & $33(65 \%)$ & .260 \\
\hline Renal disease & $52(11 \%)$ & $41(9 \%)$ & $11(22 \%)$ & .004 \\
\hline COPD & $14(3 \%)$ & $13(3 \%)$ & $1(2 \%)$ & 1.000 \\
\hline Unstable angina & $155(31 \%)$ & $140(31 \%)$ & $15(29 \%)$ & .738 \\
\hline Previous myocardial infarction & $175(35 \%)$ & $158(35 \%)$ & $17(33 \%)$ & .784 \\
\hline \multicolumn{5}{|l|}{ Heart failure, NYHA classification } \\
\hline $\mathrm{I}$ & $17(6 \%)$ & $11(5 \%)$ & $5(14 \%)$ & .313 \\
\hline II & $110(39 \%)$ & $76(37 \%)$ & $14(39 \%)$ & \\
\hline III & $94(33 \%)$ & $99(48 \%)$ & $15(42 \%)$ & \\
\hline IV & $61(22 \%)$ & $19(9 \%)$ & $2(6 \%)$ & \\
\hline \multicolumn{5}{|l|}{ LVEF $(\%)$} \\
\hline$<40$ & $69(14 \%)$ & $53(12 \%)$ & $16(31 \%)$ & .001 \\
\hline $40-59$ & $151(30 \%)$ & $137(30 \%)$ & $14(27 \%)$ & \\
\hline$\geq 60$ & $282(56 \%)$ & $260(58 \%)$ & $22(42 \%)$ & \\
\hline Reoperation & $68(14 \%)$ & $60(13 \%)$ & $8(15 \%)$ & .682 \\
\hline EuroSCORE, median (IQR) & $4(3-6)$ & $4(3-6)$ & $7(5-9)$ & $<.001$ \\
\hline \multicolumn{5}{|l|}{ Preoperative laboratory values, mean (SD) } \\
\hline Hemoglobin (g/dL) & $12.6 \pm 1.7$ & $13.3 \pm 1.7$ & $12.6 \pm 2.1$ & .009 \\
\hline Hematocrit $(\%)$ & $39 \pm 5$ & $40 \pm 5$ & $39 \pm 6$ & .071 \\
\hline Prothrombin time (s) & $11.1 \pm 1.6$ & $11.1 \pm 1.6$ & $11.4 \pm 1.4$ & .248 \\
\hline Platelet count $(\times 103 / \mu \mathrm{L})$ & $223 \pm 66$ & $224 \pm 66$ & $218 \pm 67$ & .526 \\
\hline Creatinine level (mg/dL) & $1.12 \pm 0.35$ & $1.11 \pm 0.35$ & $1.21 \pm 0.37$ & .081 \\
\hline Leukocyte count $(/ \mu \mathrm{L})$ & $7635 \pm 2065$ & $7640 \pm 2084$ & $7596 \pm 1918$ & .889 \\
\hline \multicolumn{5}{|l|}{ Preoperative drug exposure } \\
\hline Aspirin & $197(39 \%)$ & $176(39 \%)$ & $21(40 \%)$ & .868 \\
\hline Heparin & $5(1 \%)$ & $5(1 \%)$ & $0(0 \%)$ & 1.000 \\
\hline
\end{tabular}

$S D$, Standard deviation; COPD, chronic obstructive pulmonary disease; NYHA, New York Heart Association; $L V E F$, left ventricular ejection fraction; EuroSCORE, European System for Cardiac Operative Risk Evaluation; $I Q R$, interquartile range.

major postoperative complications, resulting in an area under the ROC curve of 0.72 (95\% confidence interval [CI], $0.64-0.79 ; P<.001)$ and $0.75(95 \% \mathrm{CI}, 0.66-0.83$; $P<.001$ ), respectively (Figure 1).

In a multivariate model, higher age $(\mathrm{OR}, 1.048 ; 95 \% \mathrm{CI}$, 1.011-1.086; $P=.010$ ), LVEF lower than $40 \%$ (OR, 3.03; 95\% CI, 1.200-7.510; $P=.019$; compared with LVEF of $40 \%-59 \%$, OR, 3.571; 95\% CI, 1.503-8.196; $P=.004$; compared with LVEF higher than 60\%), higher EuroSCORE (OR, 1.138; 95\% CI, 1.007-1.285; $P=.038$ ), red blood cell transfusion (OR, 1.230; 95\% CI, 1.086-1.393; $P=.001$ ), and lactate levels 6 hours after ICU admission (OR, 3.28; 95\% CI, 1.61-6.69; $P=.001$ ) are predictors of major complications (Table 4 ).

\section{DISCUSSION}

This study has demonstrated that lactate levels at the end of cardiac surgery, immediately after ICU admission and also at 6 and 12 hours later, are related to postoperative adverse events. A threshold of $3 \mathrm{mmol} / \mathrm{L}$ at 6 hours after admission to the ICU and of $2 \mathrm{mmol} / \mathrm{L}$ at 12 hours identifies patients with worse outcomes including a higher rate of 30-day mortality after cardiac surgery. Also, a lactate level exceeding $3 \mathrm{mmol} / \mathrm{L}$ at 6 hours after surgery is independently associated with a 3.3 times risk of a major complication after cardiac surgery, including death. Although the causes of these high lactate levels are numerous and diverse, these results raise the possibility that targeting therapy to reduce or prevent the initial increase in this variable may prevent complications and improve postoperative outcomes.

Cardiac surgery may result in an imbalance between oxygen demand and supply, leading to tissue hypoxia and ultimately to organ failure. ${ }^{12,13}$ Factors such as inadequate myocardial protection, residual ischemia, and longer duration of $\mathrm{CPB}$ are widely known risk factors for tissue 
TABLE 2. Intraoperative data, laboratory findings, and cardiac procedure details

\begin{tabular}{|c|c|c|c|}
\hline \multirow[b]{2}{*}{ Variable } & \multicolumn{2}{|c|}{ Complications } & \multirow[b]{2}{*}{$P$ valu } \\
\hline & No $(n=450)$ & Yes $(n=52)$ & \\
\hline \multicolumn{4}{|l|}{ Procedure } \\
\hline CABG surgery & $285(63 \%)$ & $22(42 \%)$ & \multirow[t]{3}{*}{$<.001$} \\
\hline Valve surgery & $140(31 \%)$ & $19(37 \%)$ & \\
\hline CABG + valve surgery & $25(6 \%)$ & $11(21 \%)$ & \\
\hline \multicolumn{4}{|l|}{ No. of grafts per patient } \\
\hline 1 & $28(9 \%)$ & $4(12 \%)$ & \multirow[t]{5}{*}{.395} \\
\hline 2 & $93(30 \%)$ & $6(18 \%)$ & \\
\hline 3 & $129(42 \%)$ & $15(45 \%)$ & \\
\hline 4 & $50(16 \%)$ & $8(24 \%)$ & \\
\hline$>4$ & $10(3 \%)$ & $0(0 \%)$ & \\
\hline ITA graft & $281(91 \%)$ & $28(85 \%)$ & .351 \\
\hline $\mathrm{CPB}(\min )$ & $93 \pm 29$ & $109 \pm 36$ & $<.001$ \\
\hline Crossclamp time (min) & $42(41-44)$ & $43(42-44)$ & .099 \\
\hline \multicolumn{4}{|l|}{ Hemoglobin (g/dL) } \\
\hline Initial & $12.6 \pm 1.7$ & $12.4 \pm 1.8$ & .408 \\
\hline Middle & $8.8 \pm 2.3$ & $8.5 \pm 3.2$ & .367 \\
\hline Final & $10.4 \pm 1.4$ & $10.2 \pm 1.4$ & .374 \\
\hline \multicolumn{4}{|l|}{ Hematocrit $(\%)$} \\
\hline Initial & $39 \pm 5$ & $38 \pm 5$ & .373 \\
\hline Middle & $27 \pm 5$ & $25 \pm 6$ & .019 \\
\hline Final & $32 \pm 4$ & $31 \pm 4$ & .239 \\
\hline \multicolumn{4}{|l|}{ Lactate $(\mathrm{mmol} / \mathrm{L})$} \\
\hline Initial & $1.6(1.2-1.9)$ & $1.4(1.1-1.9)$ & .442 \\
\hline Final & $3.3(2.2-4.8)$ & $3.6(2.8-5.1)$ & .018 \\
\hline \multicolumn{4}{|l|}{$\mathrm{ScVO}_{2}(\%)$} \\
\hline Initial & $74 \pm 9$ & $71 \pm 10$ & .045 \\
\hline Final & $82 \pm 7$ & $74 \pm 11$ & $<.001$ \\
\hline Fluid administered (mL) & $3000(2500-3500)$ & $3000(2500-3500)$ & .429 \\
\hline Crystalloids (mL) & $2500(2000-3000)$ & $2500(2500-3000)$ & .832 \\
\hline Albumin & $3(1 \%)$ & $1(2 \%)$ & .355 \\
\hline $\begin{array}{l}\text { Hydroxyethylstarch } \\
6 \%(130 / 0.4)\end{array}$ & $189(42 \%)$ & $28(54 \%)$ & .103 \\
\hline $\begin{array}{l}\text { Transfused RBCs, units } \\
\text { (median, IQR) }\end{array}$ & $1(0-2)$ & $2(2-4)$ & $<.001$ \\
\hline Platelet transfusion & $27(6 \%)$ & $6(12 \%)$ & .137 \\
\hline Fresh frozen plasma & $76(17 \%)$ & $21(40 \%)$ & $<.001$ \\
\hline Cryoprecipitate & $9(2 \%)$ & $2(4 \%)$ & .318 \\
\hline $\begin{array}{l}\text { Liberal strategy of RBC } \\
\text { transfusion }\end{array}$ & $229(50.9 \%)$ & $24(46.2 \%)$ & .850 \\
\hline
\end{tabular}

$C A B G$, Coronary artery bypass grafting; ITA, internal thoracic artery; $C P B$, cardiopulmonary bypass; $\mathrm{SCVO}_{2}$, Central venous oxygen saturation; $\mathrm{RBC}$, red blood cells; $I Q R$, interquartile range.

hypoperfusion and consequently for worse outcomes after cardiac surgery. ${ }^{1,2}$ Despite many advances in the care of these patients and low rates of mortality for elective cardiac procedures, complications remain frequent. Crucial to implementing adequate treatment is the definition of appropriate goals for treatment and predictive factors for complications. In sepsis, lactate levels have been used as a resuscitation end point and as predictors of both short- and long-term complications and mortality. ${ }^{5}$ In cardiac surgery, however, the role of hyperlactatemia as
TABLE 3. RBC unit exposure and lactate levels after ICU admission

\begin{tabular}{lccr}
\hline \multicolumn{1}{c}{ Variable } & \multicolumn{2}{c}{ Complications } & \\
\cline { 2 - 3 } & No $(\mathbf{n}=\mathbf{4 5 0})$ & Yes $(\mathbf{n}=\mathbf{5 2})$ & $\boldsymbol{P}$ value \\
\hline $\begin{array}{l}\text { Transfused RBC units } \\
\text { (median, IQR) }\end{array}$ & $1(0-2)$ & $2(2-4)$ & $<.001^{*}$ \\
$\begin{array}{l}\text { Lactate (mmol/L) after ICU } \\
\quad \text { admission (median, IQR) }\end{array}$ & & & \\
0 & $4(2.6-6.4)$ & $4.4(3.1-8.4)$ & $.048^{*}$ \\
$6 \mathrm{~h}$ & $2.6(2-3.6)$ & $4(2.7-5.8)$ & $<.001^{*}$ \\
$12 \mathrm{~h}$ & $1.7(1.3-2)$ & $2.3(1.8-3.2)$ & $<.001^{*}$ \\
\hline $\begin{array}{l}R B C \text {, Red blood cell; } I C U \text {, intensive care unit; } I Q R \text {, interquartile range. *Mann-Whit- } \\
\text { ney test. }\end{array}$
\end{tabular}

a marker of tissue hypoperfusion and worse outcomes is a matter of controversy.

Our results are consistent with reports in surgical and nonsurgical settings where elevated lactate concentrations and prolonged lactate clearance were associated with morbidity and death. ${ }^{14,15}$ Polonen and associates ${ }^{16}$ showed that normalizing lactate concentrations as a therapeutic goal is associated with decreased morbidity and hospital length of stay in patients undergoing cardiac surgery. Although some studies have described lactate levels higher than $3 \mathrm{mmol} / \mathrm{L}$ as being associated with worse outcomes in critically ill surgical patients, ${ }^{6,17}$ other investigations have discussed which is the appropriate range for lactate values in these patients. ${ }^{18,19}$

This study has shown that lactate concentrations higher than $3 \mathrm{mmol} / \mathrm{L} 6$ hours after ICU admission are independently associated with major complications after cardiac surgery, including death. Our data are different from the findings of Maillet and colleagues, ${ }^{1}$ who reported that higher lactate levels at ICU admission were associated with complications that included a longer duration of mechanical ventilation and length of ICU stay. We hypothesized that during surgery and immediately after ICU admission, hyperlactatemia may be due to other causes than tissue hypoperfusion, such as cardioplegia, hypothermia, and CPB.

This study brings a new perspective to the role of lactate monitoring after cardiac surgery. Previous studies have focused their attention on the moment that hyperlactatemia arises, dividing between immediate and delayed hyperlactatemia. According to these studies, patients in whom hyperlactatemia develops during their ICU stay have the same outcome as patients who have normal lactate levels during the same period. In addition, patients who have hyperlactatemia immediately after ICU admission have worse outcomes than do the other patients. ${ }^{1,2}$

The origin of the hyperlactatemia after cardiac surgery is multifactorial. Hyperlactatemia can occur even in the absence of tissue hypoperfusion. ${ }^{20}$ It can involve a reduced liver clearance of lactate secondary to the effect of the anesthetics and the low temperatures during CPB on the cellular metabolism..$^{20,21}$ In addition, the use of catecholamines 


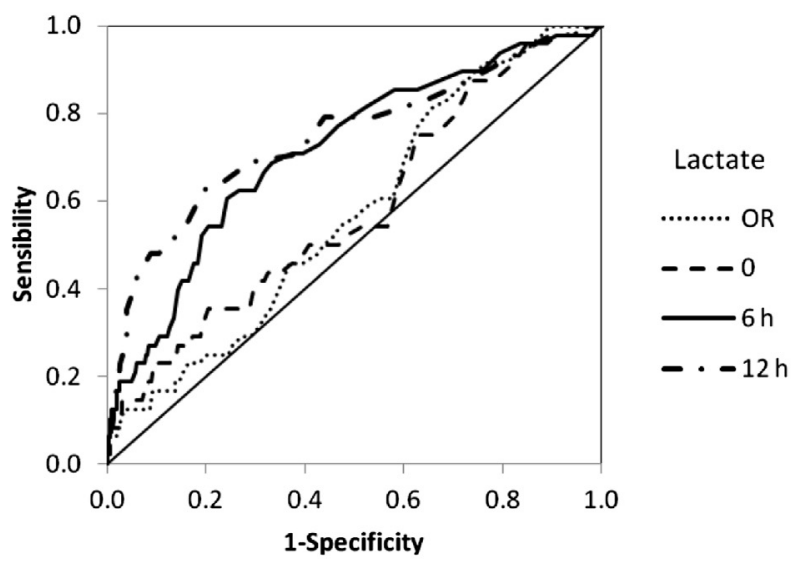

0-ICU admission

\begin{tabular}{lllll}
\hline Lactate & AUC $(95 \% \mathrm{Cl})$ & Cut-off value & PPV & PNV \\
\hline Final & $0.57(0.49-0.65)$ & $3.4 \mathrm{mmol} / \mathrm{L}$ & 0.13 & 0.92 \\
0 & $0.58(0.49-0.67)$ & $4 \mathrm{mmol} / \mathrm{L}$ & 0.11 & 0.91 \\
$6 \mathrm{~h}$ & $0.72(0.64-0.79)$ & $3 \mathrm{mmol} / \mathrm{L}$ & 0.19 & 0.95 \\
$12 \mathrm{~h}$ & $0.75(0.66-0.83)$ & $2 \mathrm{mmol} / \mathrm{L}$ & 0.23 & 0.95 \\
\hline
\end{tabular}

FIGURE 1. Receiver operating characteristic $(R O C)$ curve comparing the ability of immediate postoperative, 0-hour, 6-hour, and 12-hour lactate levels after intensive care unit $(I C U)$ admission in predicting major complications after cardiac surgery. $O R$, Operating room; $A U C$, area under the curve; $C I$, confidence interval; $P P V$, positive predictive value; $N P V$, negative predictive value.

during cardiac surgery can lead to increased lactate levels owing to their action on oxidative glucose metabolism. ${ }^{22,23}$

Patients undergoing uncomplicated cardiac surgery can often have a transient hyperlactatemia. In our study, the patients who still had lactate levels higher than $3 \mathrm{mmoL} / \mathrm{L}$ after 6 hours and higher $2 \mathrm{mmol} / \mathrm{L}$ after 12 hours of ICU stay

TABLE 4. Multiple logistic regression to determine predictive factors for major complication after cardiac surgery

\begin{tabular}{|c|c|c|c|c|c|c|}
\hline Variable & $\begin{array}{l}\text { Estimated } \\
\text { parameter }\end{array}$ & SE & OR & \multicolumn{2}{|c|}{$95 \% \mathrm{CI}$} & $P$ value \\
\hline Age (y) & 0.044 & 0.017 & 1.048 & 1.011 & 1.086 & .010 \\
\hline LVEF & & & & & & .010 \\
\hline$<40(\%)$ & & & & & & \\
\hline $40-59(\%)$ & 0.899 & 0.451 & 3.030 & 1.20 & 7.51 & .019 \\
\hline$>60(\%)$ & 1.176 & 0.426 & 3.571 & 1.503 & 8.196 & .004 \\
\hline EuroSCORE & 0.137 & 0.060 & 1.138 & 1.007 & 1.285 & .038 \\
\hline $\begin{array}{l}\text { Transfuse red } \\
\text { blood cell units }\end{array}$ & 0.195 & 0.062 & 1.230 & 1.086 & 1.393 & .001 \\
\hline Lactate $6 \mathrm{~h}$ & & & & & & \\
\hline$<3 \mathrm{mmol} / \mathrm{L}$ & Reference & & & & & \\
\hline$>3 \mathrm{mmol} / \mathrm{L}$ & 1.236 & 0.351 & 3.280 & 1.607 & 6.694 & .001 \\
\hline
\end{tabular}

could represent a subgroup of patients with hyperlactatemia secondary to occult tissue hypoperfusion. These findings suggest that a strategy of hemodynamic optimization using other parameters such as cardiac index, calculated oxygen delivery, and central venous oxygen saturation in patients with early hyperlactatemia aiming a serum lactate under 3 $\mathrm{mmol} / \mathrm{L}$ in the first 6 hours and under $2 \mathrm{mmol} / \mathrm{L}$ in the first 12 hours of ICU admission may reduce the incidence of major complications, as reported by previous studies. ${ }^{4,16,24,25}$

Other classic risk factors for worse outcomes after cardiac surgery, including increased age, lower LVEF, higher EuroSCORE, and red blood cell transfusion, were also predictors of major complications in our patients. These data are similar to other previous studies. ${ }^{25-28}$ The additional role of lactate as a risk factor suggests that in the clinical setting, it might help physicians in the perioperative planning to drive patients' monitoring and therapy.

Our study has the limitation of being performed in a single center, with a relatively small number of patients, which could restrict the generalization of our findings. In addition, we have used data from a previous prospective study that was not specifically designed for this purpose. Despite this, our data set is large and well validated, enabling us to be confident of our estimates and assumptions. 
In conclusion, lactate level 6 hours after ICU admission is an independent predictor of postoperative complications including 30-day all-cause mortality and severe morbidity after cardiac surgery in adult patients. Randomized, controlled trials are needed to evaluate the potential benefit of a strategy aiming at normalizing lactate levels after cardiac surgery.

\section{References}

1. Maillet JM, Le Besnerais P, Cantoni M, Nataf P, Ruffenach A, Lessana A, et al. Frequency, risk factors, and outcome of hyperlactatemia after cardiac surgery. Chest. 2003;123:1361-6.

2. O'Connor ED, Fraser JF. Hyperlactatemia in critical illness and cardiac surgery. Crit Care. 2010;14:421.

3. Munoz R, Laussen PC, Palacio G, Zienko L, Piercey G, Wessel DL. Changes in whole blood lactate levels during cardiopulmonary bypass for surgery for congenital cardiac disease: an early indicator of morbidity and mortality. $J$ Thorac Cardiovasc Surg. 2000;119:155-62.

4. Cheung PY, Chui N, Joffe AR, Rebeyka IM, Robertson CMT, Pediat WCC. Postoperative lactate concentrations predict the outcome of infants aged 6 weeks or less after intracardiac surgery: a cohort follow-up to 18 months. J Thorac Cardiovasc Surg. 2005;130:837-43.

5. Levy B. Lactate and shock state: the metabolic view. Curr Opin Crit Care. 2006; 12:315-21.

6. Hajjar LA, Nakamura RE, de Almeida JP, Fukushima JT, Hoff PMG, Vincent JL, et al. Lactate and base deficit are predictors of mortality in critically ill patients with cancer. Clinics. 2011;66:2037-42.

7. Leavy JA, Weil MH, Rackow EC. "Lactate washout" following circulatory arrest. JAMA. 1988;260:662-4.

8. Hajjar LA, Vincent JL, Galas FRBG, Nakamura RE, Silva CMP, Santos MH, et al. Transfusion requirements after cardiac surgery: the TRACS randomized controlled trial. JAMA. 2010;304:1559-67.

9. Massé L, Antonacci M. Low cardiac output syndrome: identification and management. Crit Care Nurs Clin North Am. 2005;17:375-83.

10. Haase M, Bellomo R, Matalanis G, Calzavacca P, Dragun D, Haase-Fielitz A. A comparison of the RIFLE and Acute Kidney Injury Network classifications for cardiac surgery-associated acute kidney injury: a prospective cohort study. J Thorac Cardiovasc Surg. 2009;138:1370-6.

11. Bernard GR, Artigas A, Brigham KL, Carlet J, Falke K, Hudson L, et al. The American-European Consensus Conference on ARDS-definitions, mechanisms, relevant outcomes, and clinical-trial coordination. Am J Respir Crit Care Med. 1994;149:818-24.

12. Li J, Schulze-Neick I, Lincoln C, Shore D, Scallan M, Bush A, et al. Oxygen consumption after cardiopulmonary bypass surgery in children: determinants and implications. J Thorac Cardiovasc Surg. 2000;119:525-33.
13. Pietersen HG, Langenberg CJM, Geskes G, Kester A, de Lange S, Van der Vusse GJ, et al. Myocardial substrate uptake and oxidation during and after routine cardiac surgery. J Thorac Cardiovasc Surg. 1999;118:71-80.

14. Bakker J, de Lima AP. Increased blood lacate levels: an important warning signal in surgical practice. Crit Care. 2004;8:96-8.

15. McNelis J, Marini CP, Jurkiewicz A, Szomstein S, Simms HH, Ritter G, et al. Prolonged lactate clearance is associated with increased mortality in the surgical intensive care unit. Am J Surg. 2001;182:481-5.

16. Polonen P, Ruokonen E, Hippelainen M, Poyhonen M, Takala J. A prospective, randomized study of goal-oriented hemodynamic therapy in cardiac surgical patients. Anesth Analg. 2000;90:1052-9.

17. Khosravani H, Shahpori R, Stelfox HT, Kirkpatrick AW, Laupland KB. Occurrence and adverse effect on outcome of hyperlactatemia in the critically ill. Crit Care. 2009;13:R90

18. Nichol AD, Egi M, Pettila V, Bellomo R, French C, Hart G, et al. Relative hyperlactatemia and hospital mortality in critically ill patients: a retrospective multicentre study. Crit Care. 2010;14:R25.

19. Valenza F, Aletti G, Fossali T, Chevallard G, Sacconi F, Irace M, et al. Lactate as a marker of energy failure in critically ill patients: hypothesis. Crit Care. 2005;9: 588-93.

20. Raper RF, Cameron G, Walker D, Bowey CJ. Type B lactic acidosis following cardiopulmonary bypass. Crit Care Med. 1997;25:46-51.

21. Takala J, Uusaro A, Parviainen I, Ruokonen E. Lactate metabolism and regional lactate exchange after cardiac surgery. New Horiz. 1996;4:483-92.

22. Stainsby WN, Sumners C, Eitzman PD. Effects of adrenergic agonists and antagonists on muscle O-2 uptake and lactate metabolism. J Appl Physiol. 1987;62: 1845-51.

23. Bellomo R. Bench-to-bedside review: lactate and the kidney. Crit Care. 2002;6: 322-6.

24. McKendry M, McGloin H, Saberi D, Caudwell L, Brady AR, Singer M. Randomised controlled trial assessing the impact of a nurse delivered, flow monitored protocol for optimisation of circulatory status after cardiac surgery. BMJ. 2004; 329:258-61.

25. Ferraris VA, Ferraris SP, Saha SP, Hessel EA, Haan CK, Royston BD, et al. Perioperative blood transfusion and blood conservation in cardiac surgery: The Society of Thoracic Surgeons and the Society of Cardiovascular Anesthesiologists Clinical Practice Guideline. Ann Thorac Surg. 2007;83:27-86.

26. Roques F, Nashef SAM, Michel P, Gauducheau E, de Vincentiis C, Baudet E, et al. Risk factors and outcome in European cardiac surgery: analysis of the EuroSCORE multinational database of 19030 patients. Eur J Cardiothorac Surg. 1999;15:816-22.

27. Mangano CM, Diamondstone LS, Ramsay JG, Aggarwal A, Herskowitz A, Mangano DT, et al. Renal dysfunction after myocardial revascularization: risk factors, adverse outcomes, and hospital resource utilization. Ann Intern Med. 1998;128:194-203.

28. Hannan EL, Racz MJ, Walford G, Ryan TJ, Isom OW, Bennett E, et al. Predictors of readmission for complications of coronary artery bypass graft surgery. JAMA. 2003;290:773-80. 